\title{
РОЛЬ НОВИХ ЕЛЕКТРОННИХ ЗАСОБІВ У ФОРМУВАННІ ВІЗУАЛЬНИХ КОМУНІКАЦІЙ ВИЩИХ НАВЧАЛЬНИХ ЗАКЛАДІВ УКРАЇНИ
}

\author{
Старший викладач, Пантус Ніна Михайлівна, \\ Студентка, Шапран Еліна Олегівна,
}

Украӥна, місто Запоріжжя, Запорізький національний технічний університет

DOI: https://doi.org/10.31435/rsglobal_ws/31032019/6420

\section{ARTICLE INFO}

Received: 14 January 2019

Accepted: 18 March 2019

Published: 31 March 2019

\section{KEYWORDS}

new media,

mobile app,

social networking,

brand,

university image.

\begin{abstract}
The article focuses on the necessity of forming the brand of a higher educational institution (HEI) with the use of more electronic means, while it is substantiated that the main tools of modern promotion are socalled new media and the use of mobile application development platforms, which are becoming increasingly popular due to the development of information of society.
\end{abstract}

Citation: Пантус Н. М., Шапран E. O. (2019) Rol Novykh Elektronnykh Zasobiv u Formuvanni Vizualnykh Komunikatsii Vyshchykh Navchalnykh Zakladiv Ukrainy. World Science. 3(43), Vol.3. doi: 10.31435/rsglobal_ws/31032019/6420

Copyright: (C) 2019 Пантус Н. М., Шапран Е. О. This is an open-access article distributed under the terms of the Creative Commons Attribution License (CC BY). The use, distribution or reproduction in other forums is permitted, provided the original author(s) or licensor are credited and that the original publication in this journal is cited, in accordance with accepted academic practice. No use, distribution or reproduction is permitted which does not comply with these terms.

Вступ. Ринок освітніх послуг, такий, що склався нині, характеризується надлишком ідентичних пропозицій, жорсткою конкурентною боротьбою за абітурієнтів. Тому вкрай важливо створити умови (інформаційно-доступні, науково-педагогічні, програмно-методичні, матеріально-технічні), які б забезпечували безперервну комунікаційну діяльність, а також використання іiі у процесі формування іміджу і соціального престижу ВНЗ, котрий залежить від низки факторів:

- якості освіти, що надається;

- загального культурного рівня студентів;

- відгуків роботодавців про випускників певного ВНЗ;

- рівня науково-інноваційної діяльності;

- внутрішніх соціально-психологічних характеристик ВНЗ;

- візуальних характеристик ВНЗ;

- засновника/керівника ВНЗ;

- рівня міжнародної співпраці.

Такий елемент як реклама $є$ основою концепції сучасного маркетингу, показує знаходження будь-якого підприємства в актуальному інформаційному просторі. Також для сучасного суспільства характерне глобальне використання комунікаційних технологій, які розглядаються, як засіб підвищення ефективності професійної і освітньої діяльності, іміджу і соціального престижу, а також підтримання бренду.

Зараз епоха швидкого розвитку інформаційних технологій. На відміну від мас-медіа, де комунікація здійснюється за схемою «від одного до багатьох», схема комунікації у нових медіа - від багатьох до багатьох. Доступ до нових медіа можливий з усіх електронних пристроїв 3 
виходом у мережу Інтернет. За даними Wordometers, станом на березень 2019 року кількість користувачів Інтернету у світі становить 4 мільярдів і постійно зростає. Статистика також повідомляє, що книжок видано близько 500 тисяч, комп'ютерів продано 73 мільйона за два місяці, а мобільних телефонів продано більше трьох мільйонів за один день [3]. Більше половини людства народженого у період розвитку інтернет технологій, зареєстровані в соціальних медіа, вміють і користуються мобільними додатками, а також є цільовою аудиторією для ВНЗ.

Метою статті є дослідження нових медіа і платформ розробки мобільних додатків як інструменту розширення візуальних комунікацій, просування послуг і підтримання бренду ВНЗ в інформаційному просторі. Відповідно до поставленої мети визначено такі завдання:

1) дослідити сутність понять «бренд ВНЗ», «нові медіа», та мобільний додаток ;

2) з'ясувати роль, види та функції нових медіа і мобільних додатків у розширенні візуальних комунікацій та просуванні послуг;

3) проаналізувати особливості маркетингу в соціальних мережах як складових частин підтримання бренда ВНЗ у інформаційному просторі.

Вважаємо за потрібне надати авторське розуміння поняттям «бренд ВНЗ», «нові медіа», «мобільний додаток», розкрити їхній взаємозв’язок. Крім того, необхідно дослідити шляхи застосування нових медіа і платформ розробки мобільних додатків як інструменту розширення візуальних комунікацій, просування послуг і підтримання бренду ВНЗ у інформаційному просторі.

Результати дослідження. Одна 3 найважливіших задач дизайну - проектування систем візуальних комунікацій, що забезпечують оптимальний зв'язок людини із середовищем - чітке і швидке сприйняття сенсу предметного оточення і регулювання процесу просторової орієнтації і поведінки [2]. Відомий канадський теоретик комунікації Маршал Мак-Люен візуальний канал комунікації вважав провідним у XX сторіччі [1]. У наш час, у XXI, столітті візуальна комунікація стала ще актуальнішою. Вже сьогодні передбачається тенденція подальшої візуалізації всіх сфер життя. Візуальні аспекти процесу комунікації набувають дедалі більшого значення. Зрозумілість, читабельність і візуальна зручність $\epsilon$ основними критеріями ефективності будь-якого повідомлення.

Одним зі способів підтримки освітнього процесу $\epsilon$ його інформатизація. Суть інформатизації у впровадженні нових інформаційно-комунікативних технологій в навчальновиховну діяльність освітнього закладу. За допомогою таких інноваційних технологій можна доповнити традиційні методики виховання або навчання, які допоможуть удосконалити процес навчання, прискорити доступ до інформаційних джерел. Інформатизація освітнього процесу полягає в підвищенні якості діяльності педагогів і студентів, цілеспрямованому формуванні інформаційної культури особистості, орієнтованому на придбання інформаційних знань, вироблення інформаційних умінь.

Зараз українські ВНЗ використовують наступні засоби візуальних комунікацій:

- друковані (плакат, листівка, брошура, буклет, журнал, газета, бланк, етикетка, календар, листівка);

- телеекранні (реклама, графічні відео і кіноролики);

- середовища або об’ємно просторові (білборди, розтяжки, електронні табло, дорожні знаки, вивіски, графіка на асфальті і стінах);

- засоби візуальної комунікації, специфічні для Інтернету (навігація сайтів різноманітного типу).

Збільшуючи застосування електронних візуальних комунікацій ВНЗ треба звернути увагу на мобільні додатки які використовують технологію доповненої реальності. Це дуже зручно, та значно покращує зацікавленість студентами паперовими носіями інформації. Не потребує дорогих грошових вкладень з боку ВНЗ. Інструмент - мобільний телефон, смартфон або планшет, являє собою базовий елемент для роботи системи і $є$ обгрунтованим з точки зору достатньої потужності мобільних процесорів, великої роздільної здатності сучасних дисплеїв та вбудованих в пристрій камер. I на сам перед є власністю людини, яка сама слідкує за його збереженістю. За допомогою мобільного інструменту викладачі, студенти і гості ВНЗ зможуть краще орієнтуватися в просторі і інформації.

Доповнена реальність - поняття, яке описує процес доповнення реальності віртуальними об'єктами. Комунікація з віртуальною реальністю виконується в режимі on-line, а 
для забезпечення необхідного ефекту необхідна лише вебкамера - зображення з якої буде доповнюватись віртуальними об'єктами [5].

Наприклад безкоштовний мобільний додаток Aurasma - оживляє сторінки журналів, фотографії, афіші та інші об'єкти масового користування, зачаровуючи користувача і з успіхом досягаючи своєї рекламної, або навчальної мети. Технологія Aurasma була розроблена в Кембриджі компанією Autonomy і вперше продемонстровано публіці в 2011 році на MipTV в Каннах. Принцип роботи Aurasma схожий 3 повсюдно використовуваною технологією розпізнавання QR кодів. Додаток використовує камеру телефону, GPS, Bluetooth, Wi-Fi, акселерометр для ідентифікації різних об'єктів 3 навколишнього простору. Надалі ці об'єкти транслюються на екрані пристрою з накладеним поверх відео, картинками, фотографіями або іншими файлами, так званими аурами. Головний плюс цього мобільного додатка не тільки в відтворені, але й наявності у додатку платформи для створення цих аур.

Групи студентів, яким було запропоновано використовувати технологію доповненої реальності в процесі вивчення навчального матеріалу, як додаткову, позитивно сприйняли та виявили велику зацікавленість до вивчення навчального матеріалу через мобільний додаток. Багато 3 них були згодні запропонувати своїм друзям, що вивчають цей предмет, теж використовувати цей додаток.

В просуванні бренду ВНЗ з’явилися нові медіа. "Нові медіа": це інтерактивні електронні видання, що комбінують формати подання інформації, різновид цифрових медіа. До нових медіа можна віднести: відео, онлайн-радіо, телевізійна трансляція, анімація, звукове оформлення. Нові медіа відрізняються від традиційних медіа користувацьким контентом, який відкритий для взаємодії і надає можливість створювати і модифікувати зміст повідомлень [8]. Нові медіа ще називають терміном «конвергентні».

Головним інформаційним ресурсом про розміщення та пошук відомостей про людей $\mathrm{i}$ події будь якого університету є сайт який оновлюється щоденно. Вищі навчальні заклади на веб-сторінці розміщують останні новини, оголошення, фотографії, звіти про проведені заходи, конференції, інформацію про наукові розробки і відкриття, контактні дані співробітників університету, студентські та адміністративні новини, анонси майбутніх подій, висвітлюються культурні та спортивні заходи тощо. Сайт є однією із ключових ланок нових медіа. Можна сказати, що соціальні мережі відіграють більш важливу роль, ніж сайт ВН3, у швидкій та якісній комунікації й популяризації навчального закладу. В наш час власні сторінки в соціальних мережах мають майже всі керівники вищих навчальних закладів (ректори, проректори, декани, директори інститутів). Що спрощує комунікацію між студентами та керівництвом вишу і дозволяє максимально швидко реагувати на будь-які зміни як усередині установи, так і за ії межами.

Якщо ВНЗ створить сторінку власного продукту (послуги, в цьому випадку — це знання) в соціальних мережах, користувачі можуть залишати на ній коментарі, рекомендації, огляди, ставити запитання та взаємодіяти один 3 одним під час обговорення певної проблеми. Будь-який відгук i коментар (позитивний чи негативний), залишений одним користувачем, може бути каталізатором для іншого i, як наслідок, спонукати до певного вибору, якщо йдеться про місце навчання.

Нові медіа, це набагато ширший спектр інструментів, який не обмежується тільки сайтом та наявністю сторінки в соціальних мережах. Розглянемо основні з них:

Блоги - це сайти, на яких записи зроблені у вигляді журнальних статей, поміток або просто цікавих посилань.

Мікроблоги - короткі оновлення статусу, що передбачають обмеження обсягу тексту.

Мобільні додатки - додатки до медійних проектів.

Фото та відеосервіси дають можливість користувачам ділитися власними фотографіями та відеофайлами. Крім того, на відміну від звичайних файлових сховищ такі сервіси функціонують спільно із соціальними мережами.

Соціальні закладки - це модернізовані звичайні закладки в браузері, які слугують для збереження необхідних сторінок. Проте соціальні закладки мають певні відмінності, оскільки зберігаються не в комп'ютері користувача, а в мережі Інтернет, що гарантує їх безпеку у разі непередбачених проблем [9]. Соціальні новини - це сайти соціальних новин збирають посилання на події, статті, зображення, опубліковані в мережі Інтернет. Усі новини оцінюються користувачами і найпопулярніші відображаються на головній сторінці ресурсу.

Подкасти — цифровий медіафайл або низка таких файлів, які розповсюджуються Інтернетом для відтворення на портативних медіапрогравачах чи персональних комп'ютерах. За 
змістом вони можуть нагадувати радіошоу, звукову виставу, містити інтерв'ю, лекції тощо. Tермін "podcast" $є$ поєднанням назви портативного програвача музики iPod та слова "broadcast".

Інтернет-форуми - це спосіб організації спілкування відвідувачів інтернет-сайту, завдяки якому можна обговорювати певне питання, читати та відповідати на повідомлення інших учасників форуму [10].

Геосоціальні мережі - соціальні медіа, що пропонують користувачам можливість за допомогою мобільних телефонів, смартфонів чи комунікаторів позначати місця, які вони відвідують.

Наприклад, Рассел Ньюман (W. Russell Neuman) професор Мічиганського університету: «New media - це новий формат існування засобів масової інформації, постійно доступних на цифрових пристроях, у яких відбувається активна участь користувачів у створенні та розповсюдженні контенту». Також він виділяє такі маркери нових медіа:

- зменшують вагомість географічних відстаней;

- дозволяють значно збільшити число зв’язків та активізують комунікації;

- надають можливості для прискорення комунікацій;

- надають можливості для інтерактивних комунікацій;

- дозволяють встановлювати зв'язки, які ще недавно частково перекривалися або ж лежали в абсолютно різних площинах [11].

Наслідком того що інші «оболонки» не надають належних технічних можливостей з'явилось таке поняття як «Електронність. Інформація сприймається інакше на мобільних пристроях, а особливо на відносно малих екранах смартфонів, ніж на дисплеях комп’ютерів. Таке сприйняття обумовлено розміром екранів і інтерфейсом телефонів та умовами в яких вони використовуються. Ними користуються постійно: вдома, в офісі, у транспорті, в чергах, у кав’ярнях, на відпочинку тощо. Такі умови заважають сприйняттю великих обсягів текстової інформації. Тому немає сенсу розміщувати великі за обсягом та не адаптовані тексти в мобільних додатках. Насправді носій інформації визначає характер повідомлення, але він не ідентичний повідомленню. На різних носіях інформація інша. Традиційні носії інформації, такі як друковані видання, дають нам константну інформацію, і мають великий суспільний сенс. У мережі інформація постійно змінюється. Жодна сторінка в Інтернеті не зберігається в незмінному вигляді, але постійно удосконалюється. Нема жодної гарантії, що доступна сьогодні сторінка збережеться завтра.

Для створення високого іміджу та репутації для навчальних закладів дуже важливо: створити бренд зі стійким іміджем, який буде демонструвати, що даний ВНЗ - «це солідний навчальний заклад 3 давніми традиціями, який здійснює підготовку студентів на високому професійному рівні 3 використанням інноваційних методів навчання і сучасного технічного оснащення»; підтримує постійний інтерес в суспільстві до життя ВНЗ; підтримує і зміцнює авторитет ВНЗ в ділових колах.

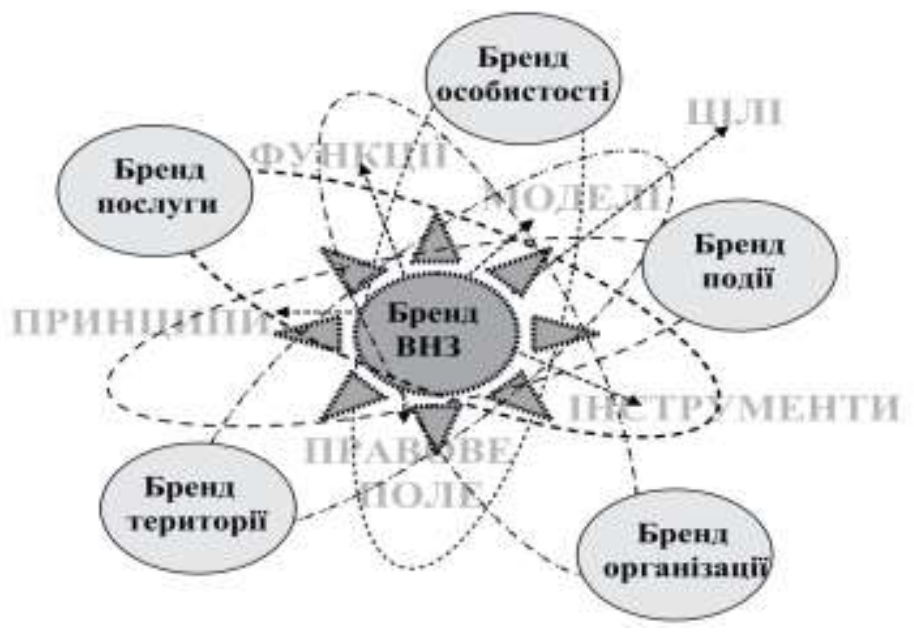

Рис. 1. Система бренда ВНЗ (розробила Студінська Г.Я.) [7]

Українські ВНЗ не позиціонують себе як бренд, мало приділяють уваги фірмовому стилю і візуальним комунікаціям. Чи то через брак коштів чи просто не розуміючи, що для процвітання компанії в сучасному світі без цього не обійтись.

Якщо проаналізувати застосування фірмового стилю і візуальних комунікацій у навчальних закладах інших країн, ми бачимо, що вони велике значення приділяють візуальним комунікаціям для створення неповторного образу навчального закладу. 
Одним із найяскравіших прикладів візуальних комунікацій які запровадив «Queen’s University Belfast», $\epsilon$ дуже розвинута система віртуальної прогулянки по всім закуткам університету. ВНЗ входить до престижної асоціації дослідницьких університетів Russell Group. Це класичний університет, що високо оцінюється в британських рейтингах та входить до топ30. Знаходиться у Белфасті (Північна Ірландія) - одному з найбезпечніших міст планети (2-е місце в світі за безпекою після Токіо за даними ООН). ВНЗ також зробив ставку на бренд особистості студентів та професорів. «Queen'sUniversity Belfast» заохочує до ведення особистого блогу студентів та всіляко допомагає в його веденні [12].

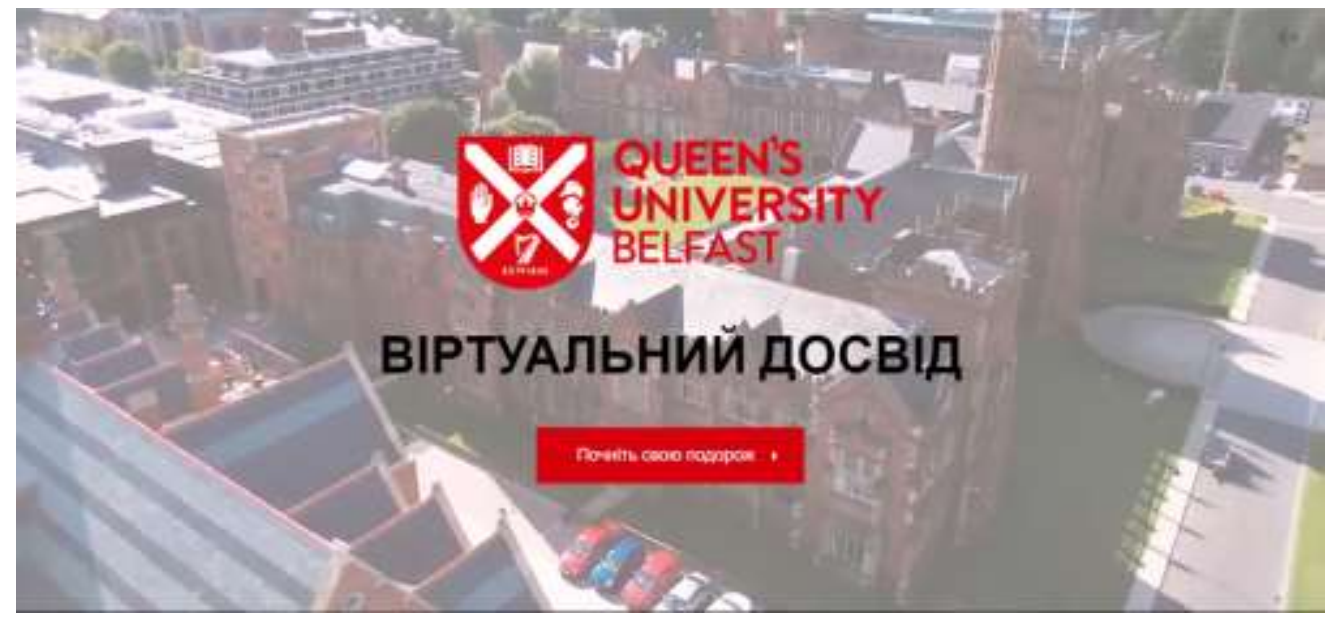

Puc. 2. «Queen's University Belfast» система віртуальної прогулянки [12]

Висновки. Таким чином можна сказати, що нові медіа можуть значно розширити та поліпшити функціонування ефективної комунікації ВНЗ. Підняти на новий рівень комунікацію у вузі, покращити його репутацію, підвищити популярність та авторитетність, удосконалити освітній процес, збільшити мотивацію студентів та стати важливим фактором розвитку ВНЗ. Крім того за допомогою технології доповненої реальності на мобільних додатках можна сформувати єдиний інформаційний ресурс, який поєднає в собі всю необхідну інформацію для повноцінного функціонування ВНЗ і буде функціонувати, як система навігації і мати дуже розгалужену структуру. Що в свою чергу знизить вартість візуальних комунікацій та підвищить рівень засвоєння графічної інформації за рахунок різноманітності і інтерактивності іiі візуального представлення.

\section{ЛІТЕРАТУРА}

1. Маклюэн Г.М. Понимание Медиа: Внешние расширения человека / Пер. с англ. В. Николаева; Закл. ст. М. Вавилова. - М.; Жуковский: «КАНОН-пресс-Ц», «Кучково поле», 2003. - 464 с.

2. Пантус Н. М. Тексти (конспект) лекцій $з$ дисципліни «Проектування» для студентів спеціальності 022 «Дизайн» спеціалізації «Графічний дизайн» денної та заочної форм навчання. $-28 \mathrm{c}$.

3. Worldometers: Real time world statistics. - Режим доступу: http://www.worldometers.info/.

4. Киричок А. Використання нових медіа у формуванні іміджу ВНЗ / А. Киричок // Вісник Книжкової палати. 2015. - № 2. - С. 42-44. - [Електронний ресурс]. - Режим доступу: http://nbuv.gov.ua/UJRN/vkp_2015_2_13.

5. Шабелюк О. В. Використання технології доповненої реальності в дистанційному освітньому процесі / О. В. Шабелюк // Вісник Київського національного університету імені Тараса Шевченка. Серія: Фізико-математичні науки. - 2014. - Вип. 2. - С. 215-218. - Режим доступу: http://nbuv.gov.ua/UJRN/VKNU_fiz_mat_2014_2_42.

6. Shirazi A. Technology-enhanced learning in construction education using mobile contextaware augmented reality visual simulation /A. Shirazi, A.H. Behzadan // Proceedings ofthe 2013 Winter Simulation Conference. - P. 3074-3085

7. Студінська Г. Я. Роль бренда освіти в інноваційному розвитку країни / Г. Я. Студінська // Моделювання та інформатизація соціально-економічного розвитку України. - 2016. - Вип. 1. - С. 84 100. - Режим доступу: http://nbuv.gov.ua/UJRN/miceru_2016_1_11.

8. Crosbie $Y$. What is New Media? - Mode of access: http://rebuildingmedia.corante.com/archives/2006/04/27 I what is new media.php.

9. Вікіпедія. - Режим доступу: http://uk. wikipedia.org/wiki/ Соціальні закладки.

10. Вікіпедія. - Режим доступу: http://uk. wikipedia.org/wiki/ Подкаст.

11. Media,technology,andsociety; theoriesofmediaevolution/W.RussellNeuman,editor.

12. Офіційний сайт «Queen'sUniversity Belfast». [Електронний ресурc]. - Режим доступу: https://www.qub.ac.uk/ 